\title{
Pembelajaran Osborn Dengan Teknik Brainstorming Berbantuan Aplikasi Matlab Materi Akar Persamaan Tak Linear
}

\author{
Harfin Lanya ${ }^{(1)}$, Septi Dariyatul Aini ${ }^{(2)}$ \\ 1,2 Dosen Prodi Pendidikan Matematika, Universitas Madura \\ Email: ${ }^{1}$ lanya.harfin@gmail.com, ${ }^{2}$ septi_math@unira.ac.id
}

\section{Tersedia Online di \\ http://www.jurnal.unublitar.ac.id/ index.php/briliant}

\begin{tabular}{l}
\hline Sejarah Artikel \\
\hline Diterima pada 28 Juli 2018 \\
Disetuji pada 3 Agustus 2018 \\
Dipublikasikan pada 13 Agustus \\
2018 Hal. 312-318 \\
\hline
\end{tabular}

\section{Kata Kunci:}

osborn, brainstorming, matlab, akar persamaan tak linear

\section{DOI:}

http://dx.doi.org/10.28926/briliant .v3i3.212

\begin{abstract}
Abstrak: Rendahnya hasil belajar mahasiswa pada matakuliah metode numerik, khususnya pada materi akar persamaan tak linear menjadi alasan peneliti untuk mengembangkan model pembelajaran Osborn dengan teknik Brainstorming berbantuan aplikasi matlab Penelitian ini bertujuan untuk menghasilkan perangkat pembelajaran yang baik dengan kriteria valid, praktis dan efektif. Oleh karena itu, penelitian ini termasuk penelitian pengembangan. Subjek penelitian ini adalah mahasiswa semester 6 yang mengikuti matakuliah metode numerik. Teknik pengumpulan data yang digunakan adalah lembar observasi dan soal kuis. Observasi dilakukan oleh seorang observer terhadap mahasiswa dan dosen selama proses pembelajaran. Sedangkan soal kuis yaitu soal urain diberikan pada pertemuan terakhir untuk mengukur kemampuan mahasiswa setelah proses pembelajaran. Perangkat pembelajaran yang dihasilkan dalam penelitian ini adalah Rencana Pembelajaran Mingguan (RPM), Lembar Kerja Mahasiswa (LKM), dan soal kuis dengan kriteria valid, praktis dan efektif.
\end{abstract}

Berdasarkan pengalaman peneliti sebagai dosen matematika di Universitas Madura menunjukkan bahwa hasil belajar yang diperoleh mahasiswa untuk matakuliah metode numerik jauh dari harapan, karena hanya 25\% mahasiswa yang memperoleh nilai diatas 80. Soal-soal yang berkaitan dengan metode numerik khususnya pokok bahasan akar persamaan tak linear dirasakan relatif sulit oleh sebagian besar mahasiswa. Sebagai contoh adalah metode biseksi yang merupakan salah satu metode numerik untuk mencari akar persamaan tak linear. Walaupun prosesnya sangat sederhana, namun mahasiswa masih mengalami kesulitan mengerjakannya dan cenderung salah pada solusi akhirnya. Hal ini disebabkan karena pada saat proses penghitungan secara manual, mahasiswa cenderung lupa dengan proses algoritmanya dan kurang teliti dalam proses menghitung.

Rendahnya hasil belajar mahasiswa dalam mata kuliah metode numerik selain disebabkan karena kecenderungan mahasiswa lupa dengan proses algoritma dan kurang teliti dalam proses menghitung, disebabkan pula karena kurang tepatnya model pembelajaran yang digunakan. Oleh karena itu diperlukan model pembelajaran dan perangkat pembelajaran yang baik. Perangkat pembelajaran menurut Ibrahim (2010) adalah perangkat yang digunakan dalam proses pembelajaran. Dalam hal ini perangkat pembelajaran adalah sekumpulan sumber belajar yang memungkinkan mahasiswa dan dosen melakukan kegiatan 
pembelajaran. Dengan adanya perangkat pembelajaran kegiatan interaksi pembelajaran menjadi lebih optimal. Sedangkan, berdasarkan Nievien (1999) perangkat pembelajaran dikatakan baik jika memenuhi kriteria valid, praktis dan efektif. Khabibah (2006) menyebutkan bahwa aspek validitas dibutuhkan ahli dan praktisi untuk memvalidasi model yang dikembangkan, sedangkan aspek praktis dan efektif diperlukan suatu perangkat pembelajaran untuk melaksanakan model pembelajaran yang dikembangkan.

Proses pembelajaran konvensional yang dominan juga merupakan salah satu penyebab rendahnya hasil belajar mahasiswa. Pada perkuliahan ini suasana kelas cenderung teacher centered sehingga mahasiswa menjadi pasif. Meskipun demikian dosen lebih suka menerapkan model tersebut, karena tidak memerlukan alat peraga dan bahan praktek, cukup menjelaskan konsep-konsep pada buku referensi yang ada. Dalam hal ini mahasiswa tidak diajarkan strategi belajar yang dapat memahami bagaimana belajar, berpikir dan memotivasi diri sendiri, padahal aspek-aspek tersebut merupakan kunci keberhasilan dalam suatu pentransferan ilmu dari dosen ke mahasiswa.

Sehingga untuk mengatasi masalah pembelajaran seperti yang diungkapkan di atas yang terpenting adalah menciptakan suasana perkuliahan yang bermakna. Di sini dituntut kompetensi dosen, dalam arti dosen harus mampu meramu model pembelajaran yang dapat menarik dan disukai oleh mahasiswa sehingga mahasiswa tidak merasa tertekan, dapat mengemukakan solusi masalah dengan bebas, berkreasi untuk mengembangkan solusi dengan curah pendapat. Salah satu model pembelajaran yang memperhatikan keadaan tersebut ketika proses perkuliahan berlangsung adalah model pembelajaran Osborn, yaitu suatu model pembelajaran dengan menggunakan metode atau teknik brainstorming. Menurut Huda (2014:148) menyebutkan bahwa langkah-langkah Osborn adalah penemuan tujuan pembelajaran, penemuan fakta, pemecahan masalah, penemuan gagasan, penemuan solusi, dan penerimaan.

Sukamti (2015) dalam penelitiannya menyatakan bahwa model Osborn dengan teknik Brainstorming merupakan model yang dapat mengaktifkan siswa untuk mencurahkan pendapat, memberikan ide-ide dalam menyelesaikan masalah. Namun, pada penelitian ini, peneliti belum menggunakan media pembelajaran guna memvasilitasi siswa dalam proses pembelajaran. Sehingga, perlu diadakan penelitian lebih lanjut untuk menerapkan model pembelajaran Osborn dengan teknik Brainstorming dengan menggunakan media pembelajaran.

Salah satu media pembelajaran yang dapat digunakan untuk mempermudah mahasiswa menyelesaikan masalah yang berkaitan dengan akar persamaan tak linear adalah aplikasi matlab. Matlab adalah sebuah software yang mempunyai kelebihan dibandingkan alat hitung lainnya. Kelebihan software ini adalah dapat membantu visualisasi grafik dalam menentukan perkiraan awal letak akar persamaan tak linear dan juga membantu melatih kemampuan penalaran mahasiswa, serta membantu pula dalam proses penghitungan sehingga penghitungan lebih cepat dan akurat (Hernadi, 2012:1).

Penelitian ini bertujuan untuk melakukan proses pengembangan perangkat dan menghasilkan perangkat pembelajaran model Osborn dengan teknik Brainstorming berbantuan aplikasi matlab materi akar persamaan tak linear yang valid, praktis dan efektif. 


\section{METODE}

\section{Jenis Penelitian}

Jenis penelitian ini tergolong penelitian pengembangan. Pengembangan perangkat yang dimaksud berupa: Rencana Perkuliahan Mingguan (RPM), Lembar Kerja Mahasiswa (LKM) dan soal kuis. Pengembangan perangkat mengacu pada model Designing Effective Instruction oleh Kemp, dkk (2011).

\section{Lokasi dan Subjek Penelitian}

Penelitian ini dilakukan di Universitas Madura Pamekasan dan yang menjadi subjek penelitian adalah mahasiswa semester 6 .

\section{Instrumen dan Teknik Pengumpulan Data}

Instrumen yang digunakan untuk mengumpulkan data dalam penelitian ini meliputi RPM, LKM dan soal kuis.

Pengumpulan data dalam penelitian ini menggunakan teknik-teknik berikut, yaitu 1) Validasi (Penilaian) yang isinya berupa lembar validasi perangkat pembelajaran terdiri dari: lembar validasi RPM, LKM, dan soal kuis. Hasil validasi para ahli terhadap perangkat pembelajaran tersebut, kemudian dianalisis dan hasilnya digunakan untuk merevisi perangkat pembelajaran. 2) Observasi (Pengamatan) dimana observasi dilakukan berkaitan dengan data kemampuan dosen mengelola pembelajaran, aktivitas mahasiswa dalam pembelajaran, dan respon mahasiswa. 3) Tes yang digunakan untuk menganalisis ketuntasan belajar secara klasikal. Ketuntasan belajar tercapai jika setiap mahasiswa memperoleh minimal 70.

\section{Teknik Analisis Data}

Adapun teknik analisis data dalam penelitian ini meliputi (1) analisis data validasi perangkat pembelajaran yang diperoleh dari validator yang memenuhi kategori rata-rata skor sebagai berikut $1,00 \leq$ rata-rata $<1,50$ tidak baik, 1,50 $\leq$ rata-rata $<2,50$ kurang baik, 2,50 $\leq$ rata-rata $<3,50$ cukup baik, 3,50 $\leq$ rata-rata $<$ 4,50 baik, 4,50 $\leq$ rata-rata $\leq 5,00$ sangat baik dan perangkat dikatakan valid jika untuk setiap perangkat berada pada kategori baik dan sangat baik. (2) analisis data kemampuan dosen dalam mengelola pembelajaran yang diperoleh dari hasil observasi dosen selama proses pembelajaran yang penilaiannya adalah $0,00 \leq$ TKD $<0,80$ tidak baik, $0,80 \leq \mathrm{TKD}<1,60$ kurang baik, $1,60 \leq \mathrm{TKD}<2,50$ cukup baik, $2,50 \leq \mathrm{TKD}<3,30$ baik, $3,30 \leq \mathrm{TKD} \leq 4,00$ sangat baik.Kemampuan dosen mengelola pembelajaran dikatakan baik jika skor dari setiap aspek yang dinilai berada pada kategori baik dan sangat baik. (3) analisis data aktivitas mahasiswa merupakan data yang dianalisis berdasarkan hasil observasi terhadap mahasiswa selama proses pembelajaran yang mana harus memenuhi penilaian sebagai berikut, yaitu $0,00 \leq \bar{x}<0,80$ tidak baik, $0,80 \leq \bar{x}<1,60$ kurang baik, $1,60 \leq \bar{x}<2,50$ cukup baik, $2,50 \leq \bar{x}<3,30$ baik, $3,30 \leq \bar{x} \leq 4,00$ sangat baik. Aktivitas mahasiswa dikatakan efektif jika memenuhi kategori baik dan sangat baik. (4) analisis data respon mahasiswa yang diperoleh dari lembar respon yang diberikan pada mahasiswa setelah proses pembelajaran yang mana respons mahasiswa dikatakan positif untuk setiap aspek yang direspons pada setiap komponen pembelajaran diperoleh persentase $\geq 75 \%$. 
(5) analisis data hasil belajar yang diperoleh dari menganalisis hasil belajar mahasiswa dalam menyelesaikan soal kuis dan hasil belajar dikatakan tuntas jika setiap mahasiswa memperoleh nilai lebih dari atau sama dengan 70 .

\section{HASIL}

Pengembangan perangkat yang dilakukan oleh peneliti berdasarkan langkah-langkah model pengembangan Kemp dengan tahapan sebagai berikut. 1) Identifikasi kebutuhan pembelajaran yang diawali dengan mengidentifikasi masalah atau analisis kebutuhan pembelajaran. Peneliti mengidentifikasi kebutuhan pembelajaran berdasarkan observasi peneliti yang sekaligus dosen pengampu matakuliah metode numerik. Berdasarkan pengalaman peneliti 2 tahun terakhir tercatat bahwa hasil tes mahasiswa masih dibawah nilai 70 khususnya pada materi akar persamaan tak linear sehingga peneliti melakukan perencanaan yaitu mencari informasi mengapa pada materi tersebut mahasiswa mendapat nilai paling kecil dibandingkan bab lainnya dan diperoleh informasi bahwa pada materi tersebut mahasiswa mengalami kesulitan dalam menyelesaikan soal tes. Tahapan selanjutnya, peneliti mengumpulkan data yaitu kesulitan yang dihadapi oleh mahasiswa terjadi karena mereka kurang memahami materi dan dosen kurang memberikan latihan soal kepada mahasiswa serta model pembelajaran yang masih bersifat "teacher centered". Sehingga, berdasarkan hal itu maka peneliti merencanakan untuk menggunakan model pembelajaran yang membuat mahasiswa menjadi lebih aktif yaitu model pembelajaran Osborn dengan teknik Brainstrorming dan memberikan banyak latihan kepada mahasiswa dengan memberikan soal latihan di LKM. 2) Analisis karakteristik mahasiswa yang menjadi subjek dalam penelitian ini adalah mahasiswa kelas A tahun akademik 2017/2018.

Diperoleh data (1) Berdasarkan hasil pretes yang dilakukan diperoleh informasi bahwa mahasiswa yang berkemampuan tinggi sebanyak 3 orang, berkemampuan sedang sebanyak 2 orang dan berkemampuan rendah sebanyak 1 orang. (2) Banyaknya mahasiswa kelas A berjumlah 6 orang yang berumur antara 20-25 tahun dan sebagaian besar dari meraka adalah anak yang aktif dan tidak malu bertanya kepada dosen ataupun teman sejawatnya. (3) Mayoritas mahasiswa sudah mengerti teknologi dan aplikasi, hampir setiap mahasiswa memiliki laptop dan menggunakan handphone android. (4) Moyoritas mahasiswa adalah anak yang mampu karena sebagian besar orang tuanya bekerja sebagai pegawai negeri. Dengan demikian, model pembelajaran Osborn dengan teknik Brainstorming berbantuan aplikasi matlab mampu diikuti mahasiswa. (5) Analisis tugas yang meliputi analisis topi dan analisis prosedur. Dalam analisis topik diperoleh informasi bahwa kurikulum yang digunakan adalah kurikulum KKNI dan dalam bab menentukan akar persamaan tak linear metode yang digunakan meliputi metode grafik, secant, aitken, biseksi, Newton-Rpahson, dan posisi salah. Sedangkan untuk analisis prosedural difokuskan pada aspek prosedur dalam menyelesaikan akar persamaan tak linear, yaitu: Memahami masalah yaitu dengan membaca LKM yang diberikan serta mencari fakta-fakta (diketahui dan ditanya) yang terdapat dalam soal LKM, Merencanakan alternatif penyelesaian yaitu dengan mencari gagasan sebanyak-banyaknya, Melaksanakan rencana pemecahan masalah yaitu dengan mencari penyelesain dari soal LKM berdasarkan sumber dan pengetahuan yang dimiliki, Mengecek atau memeriksa kembali jawaban. (6) 
Perumusan tujuan pembelajaran (kemampuan akhir yang diharapkan) dalam hal ini kemampuan akhir yang diharapkan dilakukan dengan menjabarkan capaian pembelajaran ke dalam indikator pembelajaran yang lebih spesifik. Indikator capaaian pembelajaran diuraikan sebagai berikut. (a) Mahasiswa memahami soal dan menentukan fakta-fakta yang diketahui, (b) Mahasiswa mampu menuliskan gagasan, (c) Mahasiswa mampu menemukan solusi (memecahkan masalah), (d) Mahasiswa mampu menemukan solusi terbaik (hasil diskusi kelompok), (e) Mahasiswa mampu mempresentasikan hasil kerja kelompok, dan (f) Mahasiswa mampu mengecek kebenaran jawaban menggunakan aplikasi matlab. (7) Penentuan strategi pembelajaran materi akar persamaan tak linear yang digunakan adalah diskusi kelompok, presentasi kelompok. (implementasi terlampir dalam RPM). (8) Pemilihan sumber belajar yaitu berdasarkan tujuan dan strategi pembelajaran serta analisis karakteristik mahasiswa, maka sumber belajar yang digunakan adalah LKM. (9) Perancangan perangkat pembelajaran awal meliputi Rencana Pembelajaran Mingguan (RPM), Lembar Kerja Mahasiswa (LKM) dan Soal Kuis.

\section{PEMBAHASAN}

Berdasarkan hasil uji coba untuk kelas yang menjadi tempat penelitian dan menghasilkan data sebagai berikut. (1) Data kemampuan dosen mengelola pembelajaran. Hasil observasi kemampuan dosen dalam mengelola pembelajaran pada penelitian ini adalah dalam 3 kali pertemuan pembelajaran terlihat bahwa dosen mampu menerapkan model pembelajaran dengan baik. Hal ini dibuktikan dengan nilai rata-rata yang diperoleh dosen dalam tiap pertemuan yaitu hasil observasi dosen yang diperoleh adalah 3,29, 3,60, dan 3,89. Hal ini dapat dikategorikan baik dan sangat baik. Sehingga dapat disimpulkan bahwa perangkat yang digunakan adalah praktis sejalan dengan yang diungkapkan Khabibah (2006) yaitu perangkat dikatakan praktis jika pelaksana model dapat menerapkan dengan baik. (2) Data aktivitas mahasiswa selama pembelajaran. Observasi terhadap aktivitas mahasiswa selama kegiatan pembelajaran menggunakan lembar observasi aktivitas mahasiswa. Pengamatan dilakukan oleh seorang observer terhadap 6 mahasiswa yang dilakukan sejak dimulai kegiatan sampai berakhirnya kegiatan pembelajaran. Hasilnya adalah dalam pertemuan pertama rata-rata aktivitas mahasiswa 3,38, dalam pertemuan kedua rata-ratanya 3,80 dan pada pertemuan ketiga rata-ratanya adalah 3,9. Hal ini menunjukkan bahwa aktivitas mahasiswa dalam setiap langkah ketercapaian RPM berada dalam kriteria efektif karena berada pada kategori sangat baik selaras dengan Khabibah (2006) perangkat dikatakan efektif jika pelaksana model dapat menggunakannya dengan baik. (3) Data respon mahasiswa yang diisi oleh 6 mahasiswa setelah mengikuti pembelajaran menggunakan model Osborn dengan teknik Brainstorming berbantuan aplikasi matlab materi akar persamaan tak linear. Penilain mahasiswa terhadap model ini adalah mahasiswa menyatakan setuju dalam setiap pertanyaan yang diberikan dalam angket respon yaitu 93,3\% sedangkan 6,7 \% menyatakan tidak setuju sehingga, dapat disimpulkan bahwa respon mahasiswa terhadap perangkat pembelajaran positif. (4) Data Hasil Soal Kuis yang diperoleh mahasiswa adalah rata-rata setiap mahasiswa memperoleh nilai kuis diatas 80 dan rata-rata kelas yang diperokleh 86,58 . Dapat disimpulkan bahwa hasil soal kuis adalah tuntas (Tim, 2017). Dalam hal ini soal kuis layak untuk digunakan.

316 BRILIANT: Jurnal Riset dan Konseptual Volume 3 Nomor 3, Agustus 2018 
Berdasarkan uraian di atas, maka pencapaian perangkat pembelajaran model Osborn dengan teknik Brainstorming berbantuan aplikasi matlab materi akar persamaan tak linear dikatakatan baik, karena hasil validitas ahli adalah valid, kemampuan dosen mengelola pembelajaran baik dan sangat baik, aktivitas mahasiswa efektif, respon mahasiswa positif dan nilai soal kuis dapat memenuhi kriteria yaitu tuntas. Dengan demikian, hasil pengembangan perangkat pembelajaran menggunakan model Kemp, dihasilkan perangkat pembelajaran model Osborn dengan teknik Brainstorming berbantuan aplikasi matlab yang baik untuk materi akar persamaan tak linear. Perangkat pembelajaran tersebut meliputi Rencana Pembelajaran Mingguan (RPM) untuk 3 kali pertemuan, Lembar Kerja Mahasiswa (LKM) untuk 3 kali pertemuan, dan Soal Kuis.

\section{KESIMPULAN}

Berdasarkan hasil uji coba perangkat pembelajaran dapat disimpulkan bahwa pengembangan model Osborn dengan teknik Brainstorming berbantuan aplikasi matlab adalah sebagai berikut. (1) RPM, LKM dan soal kuis valid berdasarkan hasil validasi ahli yaitu memperoleh nilai rata-rata lebih dari 4, (2) Dosen dan mahasiswa dapat menggunakan perangkat pembelajaran dengan baik, karena hasil observasi kemampuan dosen dalam mengelola pembelajaran memiliki rata-rata nilai 3.29, 3.60, dan 3.89 yang termasuk dalam kategori baik dan sangat baik serta aktivitas mahasiswa dalam setiap pembelajaran memiliki rata-rata nilai 3.38, 3.80 dan 3.93 yang termasuk dalam kategori sangat baik., (3) Perangkat pembelajaran efektif, karena mahasiswa memberikan respon positif terhadap perangkat pembelajaran dan soal kuis yang dihasilkan rata-rata setiap mahasiswa mendapatkan nilai lebih dari 70 .

\section{SARAN}

Dalam penerapan model Osborn dengan teknik Brainstorming berbantuan aplikasi matlab sebaiknya memperhatikan langkah-langkah model pembelajaran Osborn dan pengalokasian waktu dalam setiap langkah pembelajaran.

\section{DAFTAR RUJUKAN}

Hernandi, Julan. 2012. Matematika Numerik dengan Implementasi MATLAB. Yogyakarta: Andi Offset.

Huda, Miftahul. 2014. Model-model Pengajaran dan Pembelajaran.Yogyakarta. Pustaka Pelajar.

Ibrahim, Muslimin. 2010. Dasar-dasar Proses Belajar Mengajar.Surabaya. University Press.

Kemp, Jerrold E. dkk. 2011. Designing Effective Instruction sixth edition.New York. Macmillan Collage Publishing Company.

Khabibah, Siti. 2006. Pengembangan Model Pembelajaran Matematika dengan Soal Terbuka untuk Meningkatkan Kreativitas Siswa Sekolah Dasar. Disertasi.Universitas Negeri Surabaya.

Munir, Rinaldi. 2010. Metode Numerik.Bandung.Informatika.

Nievien, N.M., 1999. Design Aproaches and Tools in Education and Training. Netherland.Kluwer Academy Publisher. 
Sukamti. 2015. Pengembangan Perangkat Pembelajaran Model Osborn dengan Teknik Brainstorming Materi Aritmetika Sosial. Tesis. Universitas Negeri Surabaya.

Tim Penyusun. 2017. Pedoman Akademik Universitas Madura. Pamekasan. UNIRA. 